\title{
El patriotismo del Correo del Domingo: ficciones de guerra y soldados
}

\section{CANDELA MARINI \\ candela.marini@duke.edu-Duke University,Estados Unidos.}

Fecha de recepción: 20 de Octubre de 2017

Fecha de aceptación: 27 de noviembre de 2017

\section{RESUMEN}

El presente artículo explora la cobertura visual del periódico ilustrado Correo del Domingo en sus primeros años de funcionamiento (1864-1866), particularmente con relación a las noticias de la Guerra de la Triple Alianza (1865-1870). Siendo el semanario una de las primeras publicaciones en la región en incursionar en tácticas de periodismo visual, la primera parte del ensayo analiza los límites difusos entre las litografías de carácter informativo y periodístico, y aquéllas de carácter puramente ficcional. La segunda parte del artículo estudia cómo el periódico utiliza este carácter maleable de la imagen litográfica para sortear los problemas del reportaje visual de una guerra que no se condecía con el discurso oficialista de corte heroico y patriótico que el periódico apoyaba.
PALABRAS ClavE: Guerra del Paraguay, Guerra de la Triple Alianza, prensa ilustrada, litografías, imágenes de guerra.

\section{ABSTRACT}

This article explores the visual coverage of past and contemporary events offered by the illustrated journal Correo del Domingo during its first years of publication (1864-1866), particularly in relation to the Triple Alliance War (1865-1870). Given that the journal was one of the first publications in the region to offer forms of visual journalism, the first part of the essay analyzes the blurry boundaries between lithographs of informative, journalisticpurposeand those of more markedly fictional nature. The second part of the article argues that the journal takes advantage of the malleable uses of the lithographic image to overcome the visual coverage problems of a war that did not dovetail with the official discourse of heroism and patriotism that the journal supported.

KEYWORDS: Paraguayan War, Triple Alliance War, illustrated press, lithographs, visual journalism. 


\title{
INTRODUCCIÓN
}

El 1 de enero de 1864 comenzó a publicarse en Buenos Aires el Correo del Domingo-Periódico Literario Ilustrado. Como su títulolo indica, la publicación ofrecía una tirada semanal y salía a circular los domingos (a excepción del número inaugural, que coincidió con la llegada del año nuevo). Su misión, según anunciaban, no era política, sino social. En el primer número, el editor, José María Cantilo, proclamóla necesidad de un periódico dedicado exclusivamente al cultivo de las letras, para elevar las almas y asentar las bases "del progreso intelectual y del adelanto moral de nuestra sociedad":

\begin{abstract}
Al enviar desde hoy a la circulación el Correo del Domingo, sentimos naturalmente dudas respecto de la acogida que tendrá. Mucho recelamos que al no hallarse en él un fin político, no alcance favor entre muchas personas. Será empero un ensayo que permitirá saber si entre nosotros puede o no subsistir una publicación de esta clase, es decir, principalmente literaria. (...) Los intereses materiales, los intereses políticos tienen en nuestro país medios de publicidady estímulos que carecen deplorablemente aquellos otros, cuando debieran merecer un apoyo que ampliase su esfera (Correo del Domingo, 1 de enero de 1864) ${ }^{\mathbf{1}}$.
\end{abstract}

El recelo de Cantilo anuncia ya el espíritu arielista ${ }^{2}$ que dominaría el debate intelectual de fines del siglo XIX y principios del XX. Cantilo proponía cultivar las letras y las artes para el desarrollo del espíritu civilizado en oposición al utilitarismo de los intereses políticos y materiales. El escritor interrelacionaba estos últimos y condenaba el lugar que ocupaban en el panorama social argentino. En un tono rayano a lo catastrófico, Cantilo y los demás escritores detrás de esta publicación (Juan María Gutiérrez, Juan Carlos Gómez, José Mármol y Luis Domínguez) se imaginaban en el deber de purificar la moral, puesto que "[e]s indudable que... no se llenará un fin social, noble y directo, sino uniendo a esa amenidad [de la lectura] la instrucción, y difundiendo las ideas de moral, de caridad, de religión [;] que son las bases firmes de toda sociedad civilizada y progresista" (ibíd.). Los intereses políticos y materiales, por otro lado, no necesitaban mayor estímulo porque ya lo habían "contaminado todo":

La poesía debe levantarse a las esferas serenas, llevar al corazón siempre dolorido de la humanidad, la luz, el consuelo, la fortitud, el amor y la esperanza. Tenemos también que repetirlo con dolor. El egoísmo materialista lo ha contaminado todo, y la literatura se ve privada del noble estímulo que alienta a

1 Para facilitar la comprensión, la ortografía de las citas ha sido actualizada, a menos que se indique lo contrario.

2 El arielismo fue una corriente ideológica, crítica de las condiciones socioculturales de América Latina, que tomó su nombre del ensayo Ariel (1900) del escritor uruguayo JoséEnrique Rodó, el cual representa más bien la versión más acabada de este pensamiento, y no su comienzo (además de estas referencias en el Correo del Domingo podemos también pensar en ElEvangelio Americano (1864) del chileno Francisco Bilbao, por ejemplo). El arielismo ensalzaba la tradición grecolatina, amenazada por el utilitarismo y materialismo de la expansión capitalista-cuya mayor expresión era el imperialismo estadounidense. El arte era llamado a jugar un rol fundamental en la educación y elevación de los espíritus. Ariel expresaba también tendencias elitistas y fuertemente antidemocráticas. 
cultivar las letras, aunque proteste con energía contra esa preponderancia que pesa rudamente sobre el espíritu, obligándole a ruborizarse de sí mismo, si no se pone exclusivamente al servicio de los intereses materiales. Pone aquí punto final, porque el asunto nos llevaría lejos (ibíd.).

Quienes así se expresaban ciertamente no ocupaban un lugar marginal en la sociedad porteña de mediados y fines del siglo XIX. Al momento de fundar el Correo, Cantilo era diputado por la provincia de Buenos Aires. Con una larga y reconocida carrera como poeta, crítico, historiador y político, Gutiérrez era en ese momento el rector dela Universidad de Buenos Aires. Poetas paladines dela lucha contra Juan Manuel de Rosas, ${ }^{3}$ Mármol y Domínguez también ejercieron varios cargos políticos. Notablemente, Mármol fue enviado por Mitre a tramitar las primeras negociaciones con Brasil al comienzo de la guerra. Domínguez fue Ministro de Hacienda durante la presidencia de Domingo F. Sarmiento. Tanto Amalia de Mármol, como la Historia Argentina de Domínguez fueron por largo tiempo material escolar privilegiado en el país.

Esta posición de poder les permitió imaginar la creación de una esfera literaria libre de influencias políticas y materiales: la falsa autonomía de las

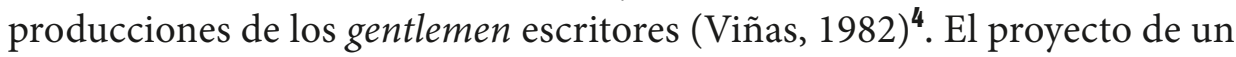
semanario para la concreción de este fin respondía a la confianza en el poder de la prensa que desde el siglo anterior era estandarte de los discursos de civilización y progreso en el mundo occidental (Eisenstein, 2011). Los progresos tecnológicos en materia de prensa se unían a la euforia de otros adelantos tecnológicos - particularmente el ferrocarril- que ayudaban a la conexión y el control de los ciudadanos.

La posibilidad de ampliar el acceso a la palabra escrita era vista como un poderoso medio de instrucción para formar ciudadanos críticos, especialmente de las amenazas antidemocráticas. Pero el Correo adoptó un discurso más ambiguo. Su énfasis en el "noble estímulo" del espíritu y la moral y, sobre todo, en la pretendida separación entre intereses políticos y estéticos, lo acercaba a posturas más conservadoras. Se trataba de educar y dictaminar la moral y el gusto estético, más que fomentar "el libre pensamiento"; consigna favorita en la prensa europea liberal y romántica, que no encuentra eco en las páginas del Correo.

3 Juan Manuel de Rosas (1793-1877) fue gobernador de la provincia de Buenos Aires en 1829-1832 y 1835-1852, logrando adquirir facultades extraordinarias y la suma del poder público. Su gobierno dictatorial empujó al exilio a la mayoría de las figuras que dominarían la escena política argentina luego de su caída en 1852. Autoproclamado defensor de la causa federalista, su figura marcó el enfrentamiento entre unitarios y federales.

4 Si bien el grupo editor era bastante exclusivo, el contenido de la publicación felizmente no se limitaba a los gentlemen, también incluía de manera consciente los perfiles y obras de "damas": "Otro de los sucesos de bulto de la quincena es la iniciación del Círculo Literario por los jóvenes Mansilla y Estrada [J. M.]. Este pensamiento ha tenido, como es de esperar, una gran acogida entre la gente inteligente. Es una idea feliz que viene a llenar una necesidad ya sentida (...). Notamos igualmente que se ha prescindido de las damas, al menos no hemos visto publicada invitación alguna; y es notorio que tenemos algunas muy capaces de formar parte de dicha asociación". (Correo del Domingo, 16 de julio de 1864). 
La república alberdiana ${ }^{5}$ de lo posible y la suma fragilidad de las instituciones y la autoridad del estado -recordemos que Buenos Aires y la Confederación ${ }^{6}$ llevaban menos de dos años unificados- parecían justificar un proyecto "sereno": "La poesía debe levantarse a las esferas serenas, llevar al corazón siempre dolorido de la humanidad, la luz, el consuelo, la fortitud, el amor y la esperanza" (Correo del Domingo, 1 de enero de 1864). Es desde este contexto de inestabilidad que surgió esta desconfianza hacia los intereses políticos. Asimismo, el semanario se negó a pensarse como una publicación de carácter efímero, anunciando desde el primer número que no se venderían números sueltos, "por cuanto esto dejaría truncas las colecciones y no permitiría encuadernar las novelas que ocuparan varios números" (ídem) ${ }^{7}$. La encuadernación como formato último revelaba la intención de crear con sus páginas una colección de consulta permanente: un archivo de las letras tanto locales como internacionales de valor imperecedero, un imaginario cultural indispensable para el progreso de una nación tan joven.

Si bien eran las letras, y en particular la poesía, lo que se privilegiaba en la publicación, las artes visuales y el contenido gráfico también tenían un peso importante. Se incluyeron reseñas sobre la exposición de obras y la apertura de escuelas y galerías. Además, se hicieron constantes referencias a las ilustraciones que el semanario divulgaba, claramente orgullosos de poder ofrecer una publicación tan completa. El carácter actual y local del contenido visual marcó un gran cambio en comparación con los periódicos ilustrados de la primera mitad del siglo; en los cuales era usual la desconexión entre texto e imagen, que utilizaban clichés muchas veces importados y que se repetían de un periódico a otro (Szir, 2009a). En el Correo del Domingo la imagen mantenía de cualquier modo un lugar subordinado respecto al texto, siguiendo la dinámica predominante en libros y periódicos ilustrados, a diferencia de la que podía darse en afiches y panfletos (Melot, 1984). El elemento visual era sobre todo valorado por su poder de atracción. La imagen funcionaba como estrategia de venta y un valor agregado. Literalmente: al anunciar un aumento de precio en la suscripción, el semanario lo justificó indicando que "es de todo punto indispensable

5 En su Bases y puntos de partida para la organización política de la República Argentina (1852), Juan Bautista Alberdi argumenta que la sociedad argentina no se encontraba aún preparada para una "república verdadera”, y que sus líderes debían primero trabajar con la "república de lo posible", pensando a sus ciudadanos más como sujetos económicos que políticos. Para escapar del fantasma de las guerras civiles y estimular el desarrollo económico-siguiendo la fórmula "orden y progreso" — se debía estimular el liberalismo económico y poner un freno al liberalismo político. Sus Bases serían efectivamente el punto de partida para la Constitución de 1853.

6 Luego de la caída de Rosas, la provincia de Buenos Aires se separa de la Confederación Argentina, en rechazo a los postulados federalistas de la Convención Constituyente de 1852. La Argentina queda formalmente dividida en dos estados hasta la extraña victoria de Mitre sobre Justo José de Urquiza en la Batalla de Pavón (1861). Santiago Derqui, presidente de la Confederación, renuncia, y Mitre asume como presidente provisional. Unos meses más tarde sería nombrado presidente constitucional (1862-1868).

7 Como muchas de sus políticas iniciales, ésta también cambiará, junto con el precio. En sus primeros números, el semanario costaba 25 pesos al mes (cuatro entregas de 16 páginas cada una). Pero meses más tarde, el 17 de julio de 1864, se anunció un aumento de precio: 30 pesos por suscripción y aceptaba ahora la venta de números sueltos por 10 pesos. En el mismo número se inauguró también el logo que se volverá encabezado permanente de la publicación ("A los suscritores", Correo del Domingo 17 de julio de 1864). 
hacer este aumento por los gastos que esta publicación demanda, sobre todo en su parte ilustrada, que le añade novedad e interés" (Correo del Domingo, 16 de julio de 1864).

En uno de sus primeros números, el Correo especuló sobre la acogida que la nueva publicación estaba recibiendo. Con el tono burlón que caracterizaba a Cantilo, la columna "Juicio crítico" no hablaba de sus lectores-cuyo juicio decía desconocer-, sino de "las personas que no han leído este periódico, que nile han visto las tapas". Cantilo imaginaba las reacciones que el periódico despertaba en la sala de una casa acomodada. Allí, una "niña”, una "ex-niña”, un "hombre de importancia", otro "hombre serio" y una "dama de importancia" se burlaban de los literatos que insistían con sus aburridas poesías y vaciedades: “ ¿Has visto, hombre, en lo que se ocupan Gutiérrez, Gómez, Mármoly Domíngueza la edad que tienen? (...) Eso es vergonzoso para hombres serios y para el país. ¡Qué dirán los extranjeros de nosotros!" (Correo del Domingo, 31 de enero de 1864). La "dama de importancia" enumeraba una lista de encargos para la "criada Policarpa", y le pedía envolver uno de los objetos en "ese papel que han traído ayer con figuras". Fue justamente Policarpa la primera en apreciar el periódico: "Señora, mire que es el Correo del Domingo con el retrato de la [cantante de ópera Carolina] Briol”. Después fue "la hija" la que advirtió que el periódico traía "unos versos muy lindos y una novela muy entretenida".

Curiosamente, si el comentario sobrela opinión extranjera parecía burlarse de la obsesión de ciertos grupos por lograr la aceptación internacional, tal actitud quedó desmentida cuando uno de los últimos comentarios positivos fue colocado en boca de "un extranjero": "ese papel debe tener algo bueno, según los hombres que en él escriben, y luego porque veo quienes le condenan sin oírlo". De esta manera, el Correo también validó la mirada extranjera - usándola para autovalidarse-. Su juicio se basaba en apariencias: el peso de los nombres de quienes escriben y los modos de quienes lo critican.

Más allá de la sorna y la broma, es patente que el semanario imaginaba un público lector variado ${ }^{9}$. Llegando a hogares pudientes en el día festivo de la tradición cristiana, la publicación aspiraba a alcanzar a lectores de diferentes clases, géneros y orígenes. Las imágenes serían el factor privilegiado para superar las barreras de poder. En efecto, es notable que la "criada Policarpa" fuela primera en apreciar el valor de la publicación, atraída por el retrato de la cantante que en ese momento ganaba aplausos con las óperas Lucía y Medea (Bilbao, 1902). En esta autoevaluación, el Correo reveló que pensaba su contenido visual predominantemente como una herramienta para atraer la atención de poten-

8 Aquí el semanario repite su deseo de llegar a las jóvenes, como anunciaba en su primer número: "Este periódico ofrecerá pues a la madre de familia la seguridad de que no irá a las manos de sus hijas, un papel cuya lectura haya podido infiltrar en sus corazones sentimientos contrarios a los que ellas han inculcado con su cariñoso afán” (Correo del Domingo, 1 de enero de 1864).

9 La imagen que inaugura el primer número muestra una multitud de personas entusiastas recibiendo las copias del Correo que Cantilo reparte. 
ciales lectores-espectadores. Eran repetidos los comentarios que apuntaban hacia esta incorporación estratégica del elemento visual: "Para dar más interés si cabe a esta obra [París en América], hemos resuelto ilustrar varios pasajes de ella. La lámina de hoy representa una de las interesantes escenas del capítulo relativo al Incendio"10. En este caso, lo visual llamaba a reforzar el interés literario en los lectores, cumpliendo así con la misión original del semanario. Sin embargo, en ese mismo número aparecieron otras propuestas en las que el atractivo visual era explotado con fines materiales y comerciales: la "contaminación" a la que el semanario inicialmente se oponía. Así se anunció la llegada de "Figurines de moda de París" (quienes querían recibirlos debían abonar cinco pesos adicionales al precio de subscripción) y "Avisos ilustrados": los comerciantes "que quieran insertar avisos en el Correo del Domingo, acompañados de una lámina representando el objeto ofrecido a venta" debían simplemente dirigirse a la administración de la Imprenta del Siglo; allí "un dibujador inteligente se encargará de copiar los objetos que se quiera para acompañar el aviso respectivo" (Correo del Domingo, 25 de junio de 1864).

Con el estallido de la Guerra de la Triple Alianza (1865-1870) llega también la "contaminación" política. Efectivamente, laintervención del gobierno argentino en esa guerra, también conocida como Guerra del Paraguay, afectó visiblemente los propósitos originales del semanario. Al transformarse la guerra civil en Uruguay en un conflicto internacional entre las potencias de la región, el tono y el contenido del semanario se modificaron. A partir de entonces, el editorial "La semana", que Cantilo firmaba bajo el seudónimo Bruno, estableció un enfoque decididamente oficialista y patriótico ${ }^{11}$. Los intereses políticos recibieron el estímulo que antes pensaba ser reservado al cultivo de las letras y las artes. Este empeño se vio secundado por las contribuciones de figuras públicas comoSarmiento, Mitre (entonces presidente de Argentina), Ricardo Gutiérrez, Marcos Sastre, entre otras tantas figuras de la escena política y cultural.

Este desvío dela misión fundadora del semanario es igualmente observable en su contenido visual. La galería de artistas que el semanario pensaba construir con los retratos de actores, cantantes y poetas que incluía en sus páginas, pasó a incluir a los "padres de la patria", tanto locales como de otras naciones (por ejemplo: José de San Martín, George Washington, Simón Bolívar). Asimismo, se agregaron modelos de figuras notables en las más variadas áreas (ciencia, industria, cultura); el criterio ahora se basaba en los aportes al progreso y a la civilización. Es el caso de la tapa que se le dedicó al Sr. D. Guillermo Wheelright, "concesionario del camino de fierro del Rosario a Córdoba" (Correo del Domingo, 23 de abril de 1865), junto con una columna dedicada a la "estadística de los

10 Ilustración de París en América; Correo del Domingo, 25 de junio de 1864.

11 Lo que no es realmente un cambio de postura, sino de peso, puesto que ya en números anteriores a la guerra se celebraban fechas patrias, incluyendo contribuciones de temática histórica. Así, en el número del 17 de julio de 1864 se publican los “Apuntes sobre el Congreso de Tucumán, por el Dr. D. Nicolás Avellaneda” y un poema de Juan María Gutiérrez titulado "A la patria en el aniversario del 9 de julio de 1816”. 
caminos de fierro de Europa y América”. A poco más de un año de su primer número, el Correo se transformó en un periódico donde la poesía era sólo uno más de sus variados intereses. El mundo material y político tenía una presencia fuerte en el corpus total del semanario. Más revelador aun, mientras la guerra se intensificaba, los retratos militares se multiplicaban.

Teniendo en cuenta las transformaciones que el contexto de guerra provocó en la agenda política y cultural del Correo, este trabajo busca analizar la incorporación de imágenes relacionadas al conflicto bélico y su uso estratégico en apoyo al discurso patriótico oficialista. Como veremos a continuación, el uso calculado del elemento visual lo llevaría a innovar en un campo poco visitado en el periodismo local: el reportaje visual de noticias. Esto ocurrió en un contexto de inestabilidad y transformación política, donde la construcción de un estado-nación llamaba a formular varias definiciones (identidad nacional, rol internacional, límites territoriales, marcas de progreso y bienestar, entre otras). Era un momento también marcado por la crisis de discursos en el mundo visual (Crary, 2005; Boehm, 2010), donde las innovaciones tecnológicas habían ayudado a poner fin a un "sistema vinculante de géneros... sistema que solía definir las coordinadas de las imágenes, el tipo de contenido y aspecto del mundo que podían tematizar, y la misión cultural que cada tipo de imagen debía cumplir" (Boehm, 2010, p. 12) ${ }^{\mathbf{1 2}}$. En este contexto de crisis y redefiniciones, este artículo indaga sobre las estrategias y mecanismos que el semanario ensayó para defender la autoridad y la verdad de sus discursos visuales. En un mundo donde la imagen va adquiriendo un peso clave en la transmisión de significados y consignas, creemos pertinente explorar los discursos anteriores a la consolidación del aparato disciplinar visual moderno (Tagg, 1993), para así comprender mejor las diferentes formas de alfabetización visual.

\section{EXPLOSIÓN DE IMÁGENES: EL REPORTAJE VISUAL}

La irrupción de la guerra de la Triple Alianza coincide con un crecimiento notable de la producción visual en Buenos Aires. Litografías y fotografías se vuelven moneda corriente en la nueva economía visual de la segunda mitad del siglo XIX (Poole, 1997; Nouzeilles, 2013). La prensa había tomado también nuevo impulso, luego del marcado declive en que había caído durante el gobierno de Juan Manuel de Rosas, especialmente en la década de 1840 (Del Carril, 1984; Szir, 2009a).

Si bien es cierto que la prensa tuvo un rol fundamental en la difusión de propaganda política durante la guerra (Toral, 2008; Díaz, 2009), el conflicto jugó en detrimento de aquellas publicaciones que buscaban intervenir principalmente en la escena cultural. Así como el Correo diversificó su contenido

12 "Following the end of a binding system of genres... a system that formerly defined the co-ordinates to which images were to refer, which contents of the world they should thematise, and which cultural mission they were to fulfill" (traducción propia). 
para incluir artículos sociales, económicos, políticos y militares, otros debieron directamente cancelar la publicación. Es el caso del periódico uruguayo El Iris. El 31 de enero de 1865, su editor, Agustín De Vedia exponía las razones de tal decisión:

\begin{abstract}
Se comprende fácilmente que la situación por que pasamos es incompatible con la aparición de un periódico literario que nadie lee ni puede leer. Por otro parte, en momentos supremos como los que golpean a las puertas de la República, es otra la misión del ciudadano. Esto explica la suspensión que sufre EL IRIS desde el presente número. (...) Cumplimos con el deber de agradecer la protección que hemos merecido y que esperamos merecer más adelante si después de la tempestad que brama en la República, logramos alcanzar días serenos, prosiguiendo en la tarea que suspendemos hoy (Correo del Domingo, 31 de enero de 1865).
\end{abstract}

El tono derrotista que De Vedia asume ("un periódico literario que nadie lee ni puede leer") intenta ser revertido con el llamado a las armas ("es otra la misión del ciudadano"). Sin cerrar sus puertas, el Correo asume también que la misión del ciudadano es apoyar la república en estos "momentos supremos". La Guerra de la Triple Alianza supondría empero un gran desafío a los poderes persuasivos del periódico. Profundamente impopular desde sus inicios, particularmente entre las regiones mesopotámicas argentinas (más cercanas a Paraguay que a Buenos Aires), la guerra fue un costo demasiado alto por los territorios ganados ${ }^{13}$, con efectos de larga duración en toda la región. La devastadora tasa de mortalidad, los levantamientos militares y políticos, la carga financiera y las vagas e insuficientes razones para intentar justificar esa masacre erosionaron la autoridad de un estado cuya unidad y estabilidad eran aún muy frágiles.

La guerra coincide así con los esfuerzos más activos en pos de la consolidación del estado-nación argentino. Parte de este proyecto es la construcción de una historia gloriosa para la nueva nación argentina. Como explica Roberto Amigo (2008), la pintura jugó un papel de peso en la creación y difusión de este imaginario nacional:

Al no estar establecido el Estado-nación moderno, con el consecuente programa de homogeneización cultural, la pintura fue una de las armas utilizadas en el debate sobre la identidad política de la Nación Argentina, considerada como preexistente a los proto-Estados de Buenos Aires y la Confederación que disputaban bélicamente la dirección de la organización estatal. Las imágenes debían instalar en la memoria colectiva los episodios fundadores con tal fuerza que se desliese la ideología política que los había establecido como verdad (Amigo, 2008, p. 10).

13 Aquéllos en disputa en la definición de los límites fronterizos del nordeste; territorios de las actuales provincias de Formosa y Misiones. 
En este escenario se desarrolló una pintura de temas patrióticos, donde las guerras de independencia e incluso la lucha contra Juan Manuel de Rosas fueron promocionadas como episodios históricos clave en la definición de una identidad argentina. El gobierno y sus allegados intentaron hacer de la Guerra de la Triple Alianza otro eslabón más en una historia gloriosa, donde la Argentina se autoinscribía como liberadora de los pueblos en tiranía. Tales esfuerzos serían poco convincentes. Como sostiene Sebastián Díaz:

Contrariamente a las hipótesis tradicionales que señalan que la guerra en el siglo XIX permiten ( $\mathrm{sic}$ ) a los estados reforzar su hegemonía sobre diferentes grupos o comunidades, borrando sus conflictos y cristalizando la nación, en el caso de las producciones durantela Guerra del Paraguay nilo visual ni lo textual pueden construir una lectura hegemónica de la nación, la patria, la república o la ciudadanía (2009, p. 13).

Su nulo tratamiento desde la pintura de historia es particularmente revelador: "ninguno de los artistas más reconocidos, con pleno dominio de los recursos técnicos, se preocupó por representar la Guerra del Paraguay, siendo contemporáneos del conflicto" (Amigo, 2009) con excepción de algunas obras que la incluyen de manera marginal. La explotación visual de la guerra para fines patrióticos quedaría entonces en manos de los considerados; según Amigo, eran artistas menores que trabajaban en los talleres de los periódicos ilustrados, por ejemplo.

Como ha estudiado Sandra Szir (2013), el Correo es una de las primeras publicaciones en el Río de la Plata que decide usar sus litografías para cubrir también eventos contemporáneos ${ }^{14}$. El 3 de abril de 1864, por ejemplo, el periódico publicó una gran lámina de dos páginas, reportando la fiesta de inauguración del ferrocarril del sur a Chascomús. El orgullo de poder ofrecer a los lectores una imagen de tal evento se ve reflejado en el espacio que esa imagen ocupó y en los detalles que ofrecía al lector sobre el esfuerzo realizado para lograr incluirla. Más novedoso aun, el 18 de diciembre de 1864 el semanario colocó en primera plana una imagen impactante del "Choque de dos trenes en el camino del Oeste, en la noche del 8 de diciembre de 1864", como indica su título.Las pocas líneas que enmarcan la vista informan que el accidentele "costó la vida al encargado del carro de encomiendas; hubo tres o cuatro personas contusas y un joven herido gravemente". La imagen es dramática e impactante:

14 Sería en las últimas décadas del siglo XIX que el uso periodístico de las imágenes adquiriría importancia: "una revisión panorámica de los periódicos ilustrados de Buenos Aires hasta la década de 1860 señala que los eventos contemporáneos no conformaban un contenido frecuente en el registro visual. Los primeros títulos privilegiaron los retratos de personajes ilustres, vistas de ciudades o paisajes del mundo, tipos o escenas de costumbres, el mundo natural en ilustraciones de inspiración científica e imágenes alegóricas. (...) El carácter de la prensa periódica como medio para cubrir noticias utilizando artistas profesionales cumpliendo tareas de reportero ilustrador fue una estrategia de la prensa europea y norteamericana que en Buenos Aires fue adoptada con los rasgos peculiares que las condiciones locales de posibilidad permitían establecer. Sus primeras manifestaciones pueden observarse en el Correo del Domingo -semanario ilustrado, de literatura, ciencias y artes- dirigido por José María Cantilo y de acuerdo con Miguel Ángel Cuarterolo "único periódico que publicaba ilustraciones con criterio periodístico" (Szir, 2013). 
entre el humo de los trenes y la oscuridad de la noche, un espacio resalta por la luminosidad que recibe; allí donde yace el cuerpo del maquinista. En estos primeros ensayos, la imagen periodística se mantenía cercana al dramatismo de las escenas de ficción. La guerra obligó al Correo a profundizar este reportaje visual. Sin embargo, no se encuentran imágenes bélicas donde la violencia y la muerte aparezcan de manera tan explícita y lamentada como en la litografía del choque de los ferrocarriles. Por el contrario, con algunas pocas excepciones, las imágenes relacionadas a la Guerra de la Triple Alianza evitaban representar la muerte de los soldados. Muy pocas incluyeron momentos de batalla o las ruinas y los cadáveres resultantes (lo que establece un claro contrapunto con las vistas de Cándido López) ${ }^{15}$.

En el reportaje visual de noticias donde el Correo estaba incursionando, la diferenciación de los discursos de verdad y ficción correspondiente a cada imagen, a cada litografía, no era algo inmediato. Esto se debe a la confluencia de imágenes de naturaleza y propósitos diversos, sin una clara distinción de géneros: en las páginas del Correo coinciden ilustraciones técnicas ("Máquina para elevar el agua en los jagüeles", Correo del Domingo, 11 de febrero de 1866); mapas y cartas ("Plano del pasaje de los aliados al territorio paraguayo en los días 16, 17, 18 de abril de 1866", Correo del Domingo, 29 de abril de 1866); noticias actuales; reportajes de moda y costumbres ("Traje para paseo a las carreras", Correo del Domingo, 10 de septiembre de 1865), tipos sociales y retratos de personajes ilustres; vistas de ciudades, edificios y monumentos ("Iglesia Nuestra Señora de Balvanera", Correo del Domingo, 7 de enero de 1866); reproducciones de pinturas ("La última oración de Jesús en el Huerto. Cuadro de D. Franklin Rawson", Correo del Domingo, 15 de octubre de 1865); recreaciones de escenas de novelas, óperas y piezas teatrales ("Margarita Pusterla", Correo del Domingo, 1 de julio de 1866); imágenes alegóricas ("La Victoria dará la Paz", Correo del Domingo, 1 de enero de 1866); e imágenes de intención histórica ("Navegación del Salado-1857. Indios moscovies (sic) ofreciendo presentes al Sr. Rams, en su viaje de exploración del Río Salado, en junio de 1857", Correo del Domingo, 2 de abril de 1865). Estas últimas, junto con las de reportaje de noticias, son las más osadas, puesto que incursionan en la representación de eventos -tanto históricos como recientes- sin necesariamente presentar garantías testimoniales, lo que Maurice Samuels (2003) llama “imágenes retrospectivas”:

Si bien las ilustraciones históricas eran difícilmente algo nuevo en el siglo diecinueve, sufren entonces un cambio radical. La historiografía ilustrada del antiguo régimen incorporaba casi de manera exclusiva iconografía producida durante la época bajo consideración-principalmente retratos de monarcas. (...) La historiografía ilustrada decimonónica, en cambio, favorecía el uso de

15 Las pinturas de Cándido López, hechas a partir de sus propios bosquejos en los campamentos y campos de batalla ofrecen visiones panorámicas del escenario bélico, al tiempo que incluyen una gran riqueza de detalles ydiversidad de situaciones (estilo derivado de las representaciones de batallas de la cartografía militar europea). En ellas, la violencia bélica queda al descubierto. Véase por ejemplo "Después de la Batalla de Curupayti”" (1893). 


\begin{abstract}
imágenes "retrospectivas", imágenes recién creadas que ofrecían una visión imaginada del pasado. Este abandono del uso exclusivo de iconografía "auténtica" permitió a las ediciones ilustradas del siglo diecinueve explorar una amplia variedad de temas: las nuevas ilustraciones tendían a enfocarse en acciones o eventos históricos, al igual que la pintura histórica, la cual naturalmente desde hacía tiempo ofrecía representaciones imaginadas o "retrospectivas" del pasado (Samuels, 2003, p. 256) ${ }^{\mathbf{1 6}}$.
\end{abstract}

Las nuevas tendencias historiográficas permitían entonces un uso más flexible de la imagen, pensándola como fuente legítima-sin importar fecha de creación- para el conocimiento del pasado (libertad que antes sólo la pintura disfrutaba). En un semanario ilustrado como el Correo, esas imágenes del pasado imaginado convivían con aquéllas de contenido abiertamente ficcional y la distinción entre unas y otras era más difusa. Si se compara, por ejemplo, una ilustración que recrea el paso de un huracán por los bosques de Palermo (figura 1) con otra que reproduce la escena de una ópera en el teatro Colón (figura 2) vemos que, si no fuera por el epígrafe que acompaña a cada litografía, poco es lo que las diferencia. Ambas imágenes llegaban al suscriptor a través del mismo medio, usando la misma tecnología, y confiando en las habilidades del mismo artista: Henri Meyer ${ }^{17}$. Incluso, el reporte del huracán reproduce el tono de las novelas que el periódico publicaba por entregas: la noticia describe cómo las familias y los grupos de amigos se habían reunido en el parque para pasar una tarde placentera de picnic y ocio, y el drama que se desata cuando el huracán los ataca por sorpresa. La litografía es descripta como un "recuerdo, aunque débil" de ese momento, y el autor del dibujo simplemente es nombrado como "el artista". Sin la diferenciación que ofrece el texto que las acompaña, poco distingue a la imagen que busca ser un apoyo cuasi-documental sobre un evento reciente de la que representa una escena de ópera que los suscriptores podían ir a ver al teatro ${ }^{\mathbf{1 8}}$.

16 "[I]f historical illustration was hardly new in the nineteenth century, it was radically transformed. Ancien régime illustrated historiography incorporated almost exclusively iconography produced during the period under consideration-primarily portraits of monarchs. (...) Nineteenth-centuryillustrated historiography, on the other hand, favored the use of "retrospective" images, newly created images offering an imaginative vision of the past. The shift away from the exclusive use of "authentic" iconography freed the nineteenth-century illustrated editions to explore a wide range of subject matter: the new illustrations tended to focus on historical actions or events, much like history painting, which of course had long offered imaginative or "retrospective" representations of the past" (Traducción propia).

17 El dibujante litógrafo francés Henri Meyer (1844-1899) fue el fundador del exitoso periódico satírico El Mosquito (1863-1893). El estudio de su figura y obra ha sido opacado por el que sería el dibujante estrella de El Mosquito, Henri Stein. Sin embargo, por los numerosos comentarios sobre sus colaboraciones en el Correo del Domingo, es patente que es objeto de gran estima y que posee considerable poder de decisión respecto a las imágenes que se publican. La reciente publicación de Claudia Román viene a llenar este vacío: Prensa, política y cultura visual. El Mosquito (Buenos Aires, 1863-1893). Buenos Aires: Ampersand, 2017.

18 Décadas más tarde la distinción de discursos en el que cada tipo de imagen debía intervenir se volvería más clara, como explica Szir respecto a las políticas de Caras y Caretas: "Los diversos géneros textuales que conformaban el material editorial del semanario estaban acompañados por determinadas modalidades visuales. De este modo, la actualidad política, social o las secciones policiales se ilustraban con fotografías; la moda, la publicidad y los textos editoriales ohumorísticos estaban asociados con ilustracioneslineales máso menos satíricas; alostextos de ficción les correspondían ilustraciones por lo general de carácter realista, más lineales o más pictóricas, acompañadas invariablemente por la firma del ilustrador" (Szir, 2009b, p. 109). 
Figura 1. "Vista de una parte del Bosque de Palermo al disiparse la oscuridad de la tarde del 19 de marzo de 1866". Correo del Domingo, 25 de marzo de 1866.

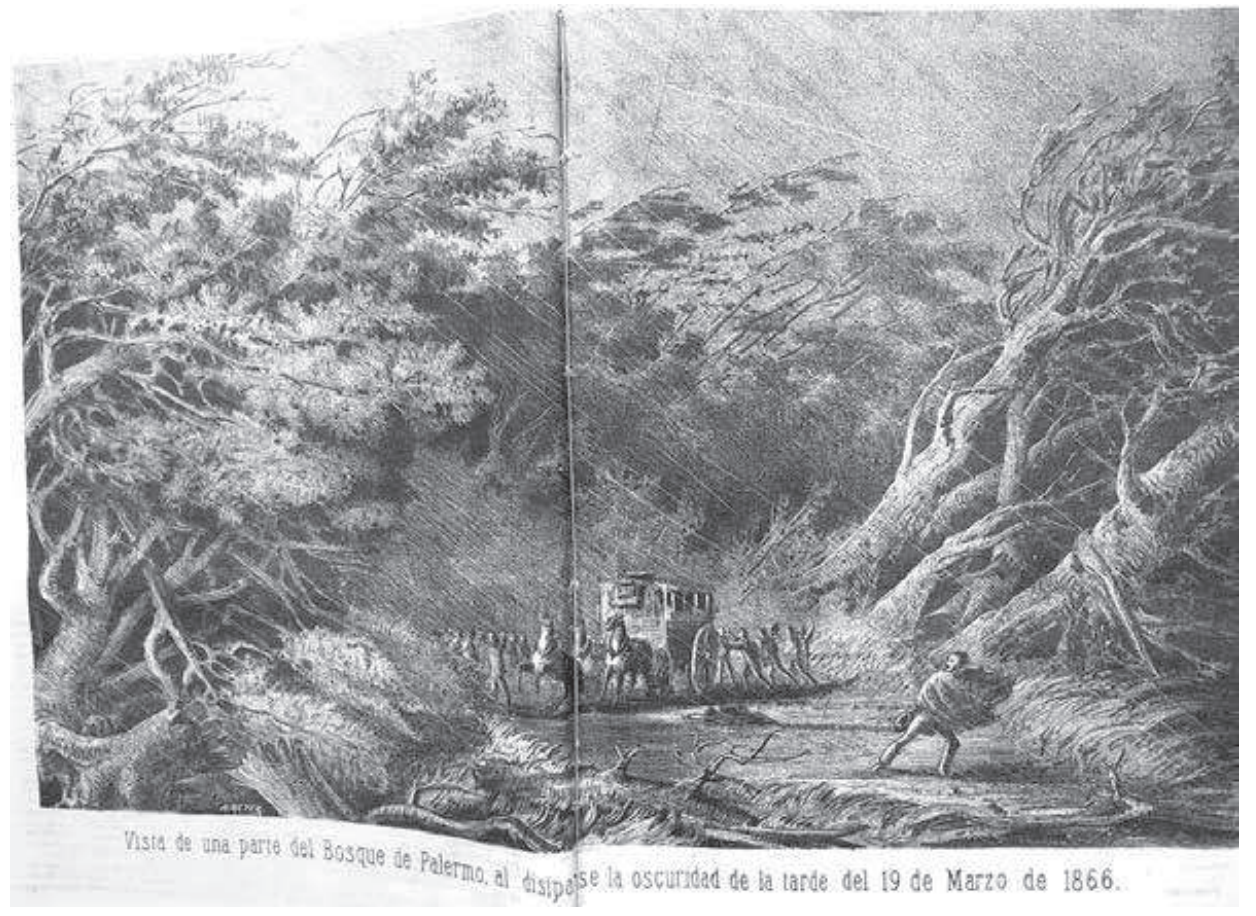

Figura 2. "Teatro Colón - Escena del último acto de la 'Forza del Destino"'. Correo del Domingo, 16 de septiembre 16 de 1866

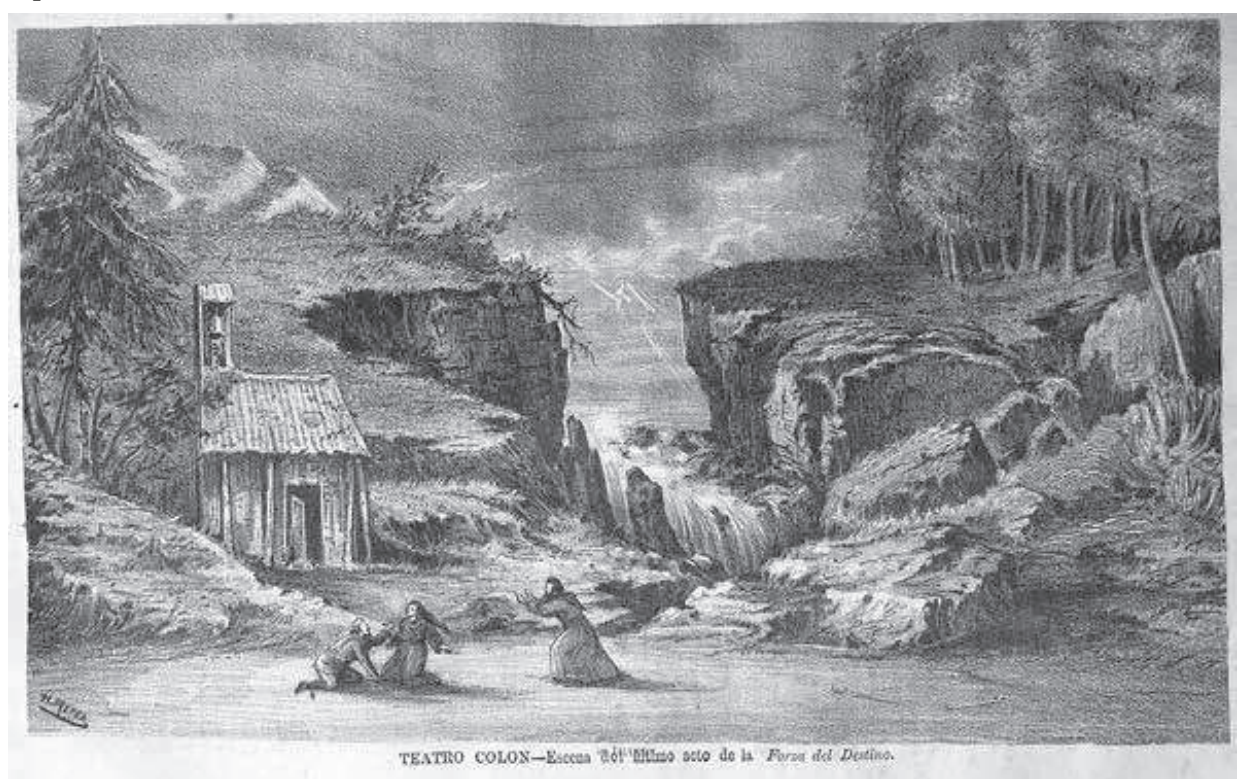

Esta misma flexibilidad de sentido de la imagen litográfica -adaptable a la ficción y al reportaje- sería explotada en las imágenes relacionadas con la 
guerra. En efecto, el periódico jugó con diferentes registros visuales y textuales para intentar sostener una imagen gloriosa del conflicto y sus guerreros; gesto que la pintura había elegido evitar. Sin embargo, en la elección y origen de las imágenes es posible apreciar una constante tensión entre lo que la guerra debía ser y parecer (otro evento épico de la talla de las guerras de independencia), y el horror de una violencia absurda, sin una distancia temporal que pudiera borrar sus efectos.

\section{GLORIA Y HEROISMO EN LA GUERRA DE REDENCIÓN DEL PARAGUAY}

Sin identificarse con la mirada satírica de revistas como El Mosquito ${ }^{19}$ posicionándose más bien como una publicación "seria", los editoriales del Correo asumieron un tono burlón que no escondía una agenda política y cultural marcadamente oficialista, donde la guerra y la definición de una nación argentina pasaron a ser cuestiones centrales ${ }^{20}$. Sin embargo, el discurso glorioso de la guerra que el Correo buscaba rescatar-aquél basado en héroes, batallas, ideales y causas nobles- entró en crisis precisamente cuando esos ideales se volvieron esenciales para el proceso de construcción nacional ${ }^{21}$.

Según la interpretación oficial argentina, la guerra buscaba liberaral pueblo paraguayo del tirano que lo mantenía aislado del mundo civilizado. Bajo esta luz, la guerra del Paraguay era la última instancia de la empresa libertadora que las fuerzas argentinas habían asumido durante las guerras de independencia. En otras palabras, la Argentina se autoproclamaba defensora de los pueblos americanos, luchadora contra todo tipo de opresión. Esta narrativa seinsertaba dentro de un discurso de construcción nacional que ensalzaba el momento de las guerras de independencia como cuna de la historia e identidad nacional. Un poema de Ricardo Gutiérrez, publicado en el Correo el 23 de abril de 1865, resume esta mirada:

19 ElMosquito (1863-1893) fue un semanario satírico fundado por Henri Meyer, que alcanzaría mayor popularidad a partir de la incorporación del dibujante Henri Stein. Su parte gráfica, principal atractivo, comentaba la actualidad política y social.

20 Aunque conforme la publicación madura, el contenido se diversifica al punto de incluir sátira visual (como la contratapa del 22 de octubre de 1865) o incluso juegos de adivinanza visual (en la sección de "jeroglíficos").

21 Esta crisis del discurso heroico de la guerra se presenta en variadas regiones a lo largo del siglo XIX. Como explica Laurence Bertrand Dorléac, si bien siempre existieron discursos críticos a la violencia bélica, no es sino hasta las guerras napoleónicas que tal violencia es desautorizada en obras que la muestran en todo su horror y absurdidad: "Longtemps, la guerre fit non seulement partie de l'histoire des sociétés mais elle semblait en assurer l'ordre, les fièvres nécessaires, la violence autorisée, ritualisée, glorifiée. Même si l’on n’aimait déjà pas ses conséquences et même si la peinture faisait allusion a ses désastres sans y insister, elle s'inscrivait avant tout dans un cycle d'héroïsation. (...) C’est Goya et Géricault qui allaient tirer au plus vite la meilleure leçon visuelle des effets de [le] hubris [de Napoléon]. Les deux actaient la contradiction née de la naissance de l'individu dans la Révolution qui n'acceptait déjà plus les désastres dela guerre sans en voir l’absurdité. (...) Après les campagnes de Napoléon, la guerre ne serait plus seulement grandiose et ses conséquences sur les êtres et les choses désormais inscrites visuellement risquaient à tout moment d'être considérées comme fascinantes mais absurdes" (Bertrand Dorléac 2014, pp. 17-19). Los grabados de Goya "Los desastres de la guerra" serían publicados póstumamente en Madrid en 1863; desconozco en qué momento llegaron al Río de la Plata. 


\title{
LA REDENCIÓN DEL PARAGUAY22
}

\author{
Se estremece la tierra \\ donde abatió la frente el león Hispano, \\ donde se hundió el orgullo de Inglaterra \\ y el hijo del soberbio Lusitano! \\ Se estremece la tierra \\ donde la espada de Belgrano! \\ La fuerza del destino, \\ Atila de la América, te lanza \\ sobre el suelo Arjentino!... \\ La voz del Paraguay pide venganza, \\ y el pueblo justiciero \\ que hundió en sus montes su primer verdugo, \\ vuela á romper sobre tu frente el yugo, \\ de su opresor postrero! \\ Ah! Por eso resuena \\ sobre la tierra clásica de Mayo \\ el golpe de tu planta, paraguayo, \\ uncida al eslabon de tu cadena! \\ Hija infeliz de la Nacion que un día \\ alumbró sobre el mundo \\ de San Martín la formidable Espada!... \\ Patria despedazada \\ en noche de vergüenza y tiranía, \\ oh! templa un tanto tu dolor profundo!... \\ ya te escuchó la tierra \\ donde abatió su frente el león Hispano, \\ donde se hundió el orgullo de Inglaterra, \\ y el hijo del soberbio Lusitano! \\ Ya te escuchó la tierra \\ de Alvear, de San Martín, de Belgrano! \\ Y tú, pueblo del Sol, patria sublime, \\ el estandarte de tus glorias bate, \\ sobre el escudo de tus padres toca \\ y de nuevo redime \\ á precio de sangre \\ al hermano que jime \\ atado á la cadena de una roca? \\ Tumba de tres coronas \\ que liberaste el mundo Americano! \\ levanta el himno que en la lid entonas \\ porque llama á su tumba otro tirano!
}

86

Como ya lo anuncia el título, no se trata de una guerra contra Paraguay, sino por (la salvación del) Paraguay. El hermano en cadenas reclama que de la tierra vecina vuelvan las espadas que libertaron "el mundo americano". Las

22 Ortografía original. Vale señalar que uno de los poemas más recordados de Gutiérrez es precisamente otro que lamenta la guerra, "La Victoria" (publicado en La Revista Argentina, 1868). 
figuras y los principios del período independentista eran invocados para insertar al nuevo conflicto dentro de la narrativa heroica con la que se estaban interpretando las guerras contra el imperio español. El Correo publicó también varios artículos históricos referentes a esos primeros momentos de la nación argentina, comolas biografías de Manuel Belgranoy Joséde San Martín escritas por Mitre.

Lo que la poesía y los editoriales podían retratar a gusto suponía un desafío para la parte ilustrada del periódico. En primer lugar, se intentaba rescatar la imagen del soldado como ejemplo de virtud republicana. Como señalamos antes, a partir de la caída de Rosas (1852), Buenos Aires comenzó a sentar las pautas de lo que sería la historia nacional de "héroes" y "eventos gloriosos", apoyándose fuertemente en la historia bélica. Las pinturas y las láminas de las décadas de 1850 y 1860 proyectaron el tipo de discurso patriótico y republicano que luego el Correo retomaría e impulsaría al estallar la Guerra del Paraguay. Guardia Nacional (1858) y Partida de la Guardia Nacional al embarcarse (1862) de Jean-Léon Pallière y Desembarco de tropas de Buenos Aires después de Pavón (1862) de Luigi Novarese son algunos ejemplos de la promoción del ideal republicano del "ciudadano armado", en el que clases y razas quedaron igualadas bajo el uniforme militar, en defensa de ideales y valores compartidos (Amigo, 2008). La virtud que antes el Correo quería estimular por medio de la poesía será luego representada por los valerosos soldados de la nación. Se dejaba la pluma para levantar la espada.

Sin embargo, las imágenes del Correo dialogaban no solamente con las pinturas de tema histórico y patriótico, sino también con la multiplicidad de imágenes circulantes facilitada por la creciente innovación tecnológica en fotografía y formatos de reproducción visual. Como explica André Toral (2008):

El surgimiento y consolidación de la fotografía y de la prensa ilustrada... limitaron en mucho el papel de la pintura académica [como] fuente única de registro de la guerra. Su producción era pequeña y restricta a la corte y a los salones de bellas artes. El público "vio" la guerra fundamentalmente a través de grabados y fotografías. Durante la Guerra del Paraguay la fotografía dejó de ser únicamente retrato y referencia para la pintura. Afirmó su valor como forma de registro histórico y autónomo. (...) La pintura académica como posibilidad de representación de la nación perdió bruscamente su hegemonía. (...) La fotografía y la litografía eran los medios que más se acercaban a ese pretendido realismo, ahora convertido en paradigma de modernidad (2008, pp. 220 y 221 ; énfasis añadido).

Con la explosión de la guerra, los estudios fotográficos rápidamente aprovecharon este nicho comercial. Las económicas cartes-de-visite permitían a los soldados dejar su retrato ante la incertidumbre de la vuelta. Asimismo, fueron convenientemente populares los retratos de figuras políticas y militares que 
protagonizaban la contienda; con mayor distribución especialmente después de una batalla importante o siguiendo un anuncio de defunción. El Correo seguiría una lógica similar en la serie de retratos con la que llenó sus páginas, manteniendo sin embargo un alineamiento claro con el discurso conservador de la guerra. Los retratos de los oficiales heridos o caídos eran acompañados de columnas biográficas que alababan su accionar heroico, y los retrataban como modelos a seguir. Dejando a un lado los resultados concretos en el campo de batalla, estos perfiles ayudaban a desviar la atención respecto al no-avance y mortandad de la guerra, al tiempo que simulaban informar sobre ella.

Prefiriendo una representación ficcionalizada de los soldados, el Correo ignoró los cientos de fotografías en circulación (tanto retratos, como protoreportajes de los campamentos y los campos de batalla), y eligió en cambio hacer sus propias representaciones de aquéllos a quienes también definía como héroes. Fue entonces que la naturaleza indefinida de la imagen litográfica resultó particularmente ventajosa. A pesar de la numerosa cantidad de fotografías de soldados, el periódico elegía divulgar sus propios dibujos idealizados de las fuerzas militares argentinas. Las libertades que se tomaban en estas representaciones eran especialmente osadas en la primera parte del conflicto. El 1 de octubre de 1865, por ejemplo, el semanario publicó una lámina que "representa una escena de campamento" durante el sitio de Uruguayana (figura 3).

Figura 3. "Una noche de campamento frente a la Uruguayana". Correo del Domingo, 1 de octubre de 1865

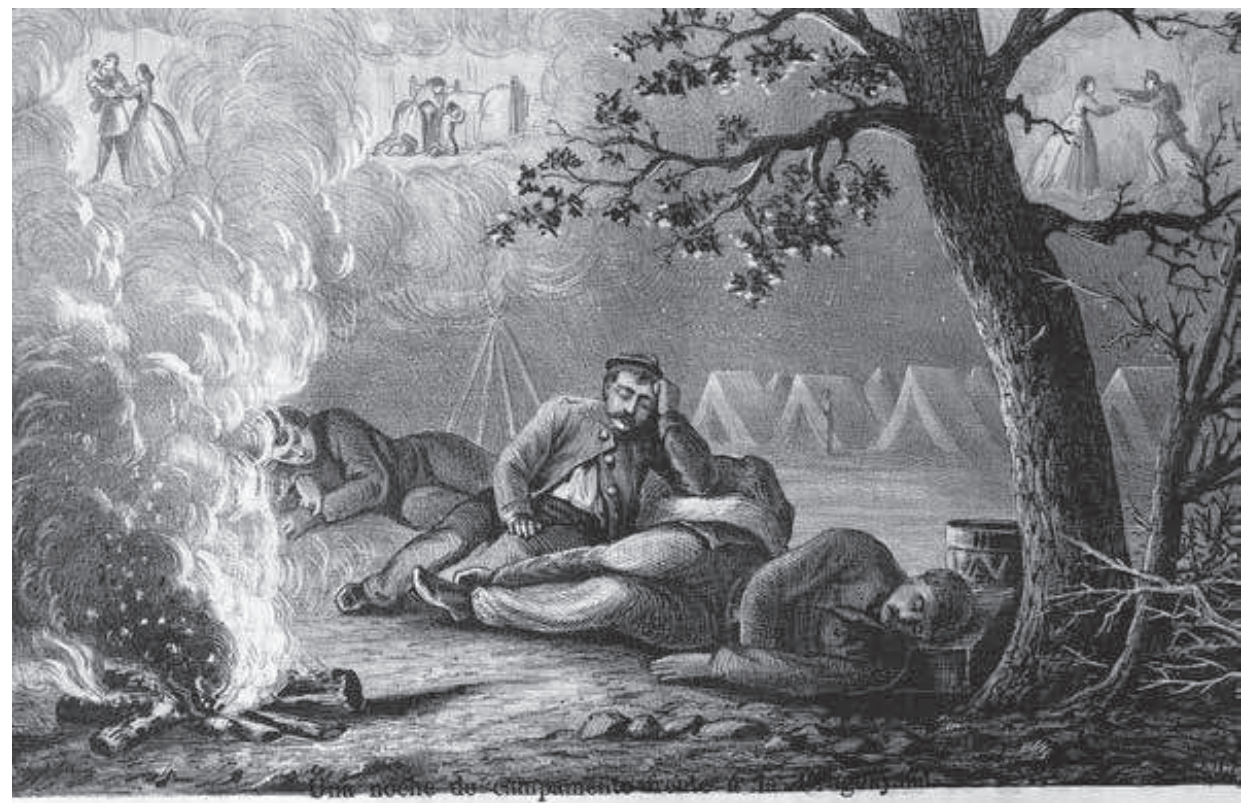

La exitosa rendición de la ciudad parecía justificar un espíritu particularmente optimista: 


\begin{abstract}
La lámina de la última página representa una escena de campamento. El ejército se preparaba a dar al día siguiente el asalto a la Uruguayana. Nuestros soldados reposan en la confianza de la victoria; pero ¿qué guerrero por esforzado que sea, [no] vuela en sueños al hogar, no habla con la esposa y los hijos, con la tierra prometida, con los amigos, no vuelve a pasear por los lugares donde ha dejado pedazos de su corazón?

Esos tres soldados sueñan pues, y se sienten trasportados al seno de sus más dulces afecciones, terminada felizmente la campaña que ha de dar por resultado el desagravio de grandes ofensas y la regeneración de un pueblo ("Una noche de campamento frente a la Uruguayana", Correo del Domingo, 1 de octubre de 1865).
\end{abstract}

La interpretación de la lámina es guiada no solamente por estas palabras, sino también por la litografía que se presenta en la tapa:la primera imagen que el lector recibe es la de una multitud mayoritariamente masculina que levanta sus sombreros y galeras celebrando las "BUENAS NOTICIAS" que el semanario anuncia en mayúsculas. En la siguiente página, la columna de Bruno explica: "ahí está ese grupo formado delante de la entrada de la capitanía del puerto que celebra la caída de la Uruguayana con un gozo exento de todo pesar".

Precedida por estas palabras e imágenes de "gozo exento de todo pesar", la lámina reportando sobre la vida en el campamento, muestra tres soldados durmiendo plácidamente al aire libre. El humo del fuego que han olvidado apagar se transforma en las nubes que representan sus sueños; de vuelta en casa y no en la guerra. Así, la litografía que informa sobre la vida de los soldados imagina no sólo su presente -calmado y seguro-, sino también el futuro victorioso y pacífico. La crónica sobre los soldados en el campamento y el frente de batalla apela a la narración, a la ficción, aunque sin renunciar a su misión informativa. Esta última se insinúa al indicar el momento exacto en que esta escena tiene lugar: la noche anterior al asalto a la ciudad de Uruguayana. El semanario abre su número con el después del asalto (la celebración) y lo cierra con el momento anterior al asalto, el cual, en retrospectiva, lejos de ser uno de preparación y ansiedad, es de parsimonia y reposo ${ }^{23}$. Meyer, el artista detrás de esta lámina, divide la escena en dos mundos. La escena superior, encuadrada por el humo y las ramas protectoras de un árbol, muestra los sueños de los soldados, aquello que secretamente anhelan mientras continúan sirviendo a la patria, como nos aclara también el Correo. Fuera de ese mundo nebuloso, el resto de la escena se presenta más claro y despejado, y, en comparación, más convincente. Al informar sobre los sueños de los soldados, el periódico logra desviarnos del hecho de que los tres soldados durmiendo junto a una fogata, entre follaje y tambores, eran también completamente imaginarios.

23 Notablemente, el antes y después de una batalla, así como las escenas de campamento y los retratos de oficiales, son las imágenes de guerra que la fotografía de entonces nos ofrece (por limitaciones técnicas, el accionar de la batalla quedaba fuera del relato bélico fotográfico). 
Si era posible jugar con las representaciones de quienes estaban lejos, lo que ocurría en la ciudad suponía un reto más difícil de sortear. Ciertamente, otra tensión en la cobertura de la guerra se encuentra en la incongruencia que el periódico encuentra entre una esperada "elegancia bélica" y el desencanto reinante en las calles y salones de Buenos Aires:

Todavía no ha tomado la ciudad el aspecto militar que debe tener, porque la guardia nacional no ha recibido su uniforme de marcha. Mas ya se cuentan por centenares los jóvenes oficiales que lo visten, prontos a emprender la gloriosa campaña ("La Semana", Correo del Domingo, 28 de mayo de 1865; énfasis añadido).

La impaciencia de Cantilo por ver patentes los aspectos más llamativos y glamorosos de la situación bélica venía en aumento desde números anteriores. Tres semanas antes, el periódico había presentado en su primera plana imágenes de los combatientes de las diferentes fuerzas del país con sus correspondientes uniformes. En ese número del 7 de mayo de 1865, la columna de Cantilo celebraba por adelantado el arribo de estos uniformes y los desfiles militares que decorarían la ciudad: "dentro de pocos días veremos cuatro mil hombres de la ciudad luciendo su blusa azul”. Curiosamente, esos tipos litográficos parecen haber sido copiados del periódico francés L'Illustration, aunque nada se dice de esta fuente en el Correo. En efecto, el 5 de noviembre de 1864, L'Illustration había publicado un extenso artículo comentandola situación política yeconómica de Paraguay, Uruguay y Argentina ("Les états de La Plata"). Respecto a este último país, el artículo pondera extensamente sus fuerzas armadas, resaltando una y otra vez la influencia francesa. Esto explica el espacio dado a las ilustraciones de los soldados. El Correo reproduce estos modelos franceses con la esperanza de que pronto correspondan con la realidad de las calles porteñas, pero el texto que las acompaña tiene dificultades en defender tal imagen, jugando con las promesas de los "todavía” y "dentro de poco".

Otro ejemplo que ayuda a ilustrar los problemas periodísticos quela Guerra del Paraguay supuso para un periódico de agenda tan patriótica lo ofrecen las colaboraciones de Nicolás Granada, combatiente, hombres de letras y artista aficionado. El 25 de febrero de 1866, el Correo publicó unas láminas de su autoría junto con una carta en la que enfatizaba el carácter de primera mano de su testimonio:

Los diarios de la capital han dado con más o menos detalles, con más o menos verdad, las noticias de este hecho de armas que ha venido a añadir una página a nuestros fastos gloriosos. El parte oficial ha dado cuenta con su lenguaje lacónico y preciso de lo sucedido sin más comentarios ni digresiones. (...)Pero en todas las noticias, relatos y detalles, se han dejado en blanco los relatos de valor que ese día tuvieron lugar, y que tal vez por su aislamiento, o por la modesta esfera de sus autores, no ha hallado más eco que el del campamento. 
(...) Acompaño estas líneas con un ligero dibujo del combate del 31 de enero, tomado en el momento en que nuestros infantes cargaban a la bayoneta sobre el enemigo, obligándolo a arrojarse precipitadamente al rio o a perecer bajo la punta de nuestros aceros. Este pequeño trabajo dará a nuestros lectores una idea, aunque pálida, de este combate, en que las armas argentinas conquistaron un laurel más para la corona de sus triunfos. ("Cuartel General de la Ensenada”, Correo del Domingo, 15 de febrero de 1866; énfasis añadido).

Granada denunció un vacío, un espacio "en blanco" en los reportes y en los artículos sobre la guerra: el de los pequeños actos de heroísmo que sólo son celebrados en las fogatas de los campamentos. Según Granada -y el Correo-, el heroísmo de los soldados argentinos era invisibilizado. Si el público en Buenos Aires no escuchaba ni veía esas historias, no era porque estos actos heroicos no existieran, sino porque se los estaba ignorando. Las litografías de los dibujos de Granada tienen aquí autoridad testimonial: no son fotografías, pero el dibujo es "tomado en el momento". Con esta convicción documental, los dibujos de Granada vienen a tapar la alarmante ausencia de imágenes gloriosas en la visualización de la Guerra de la Triple Alianza. La litografía del combate del 31 de enero de 1866 (figura 4) es una de las pocas instancias en que el semanario se atreve a publicar una imagen de combate y muerte. El semanario nuevamente combina texto e imagen estratégicamente para que tal escena sea recibida con

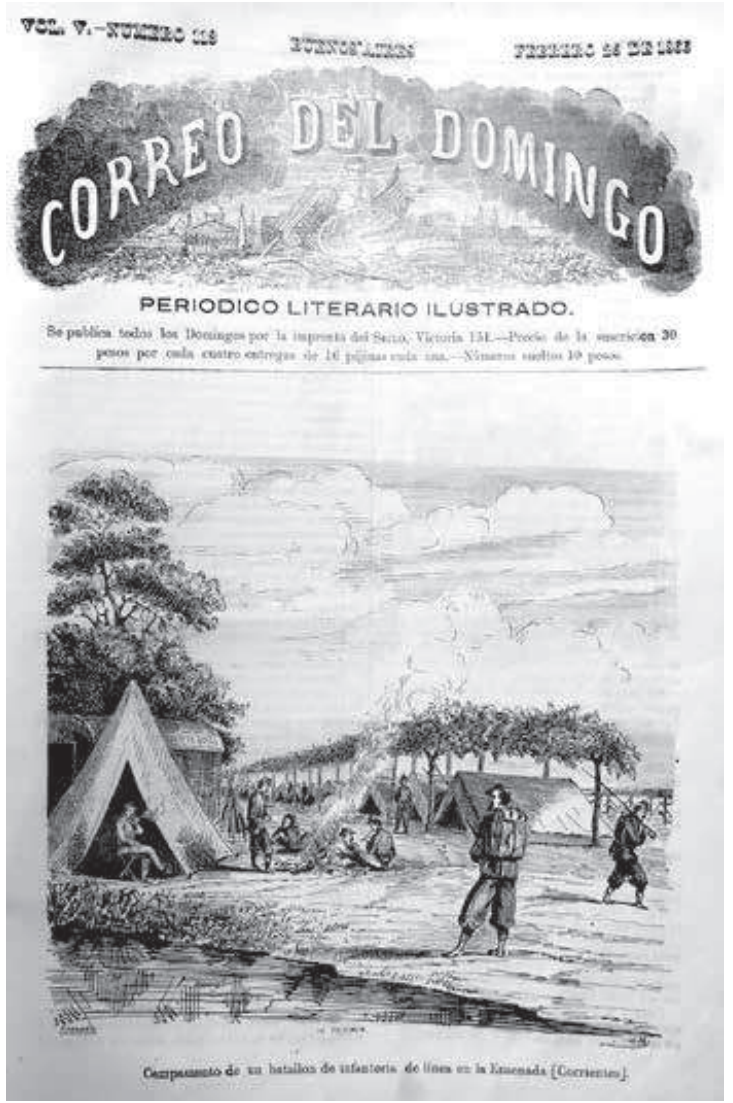
tranquilidad y admiración. Por un lado, el texto se ocupa de enfatizar el heroísmo de los soldados y el triunfo del combate, aclarando que los caídos y en huida son soldados enemigos. Visualmente, el lector es preparado con la litografía que abre el número (figura 5), donde nuevamente se muestra una escena de campamento, donde prima el reposo y la camaradería. De esta manera, el lector podrá asociar estos soldados con los que luego verá luchando -ya sabe- victoriosamente.

Figura 4. "Campamento de un batallón de infantería de línea en la Ensenada (Corrientes)". Correo del Domingo, 14 de enero de 1866. 
Figura 5. "Combate del 31 de enero en el Paso de la Patria. Carga a la bayoneta". Correo del Domingo, 25 de febrero de 1866.

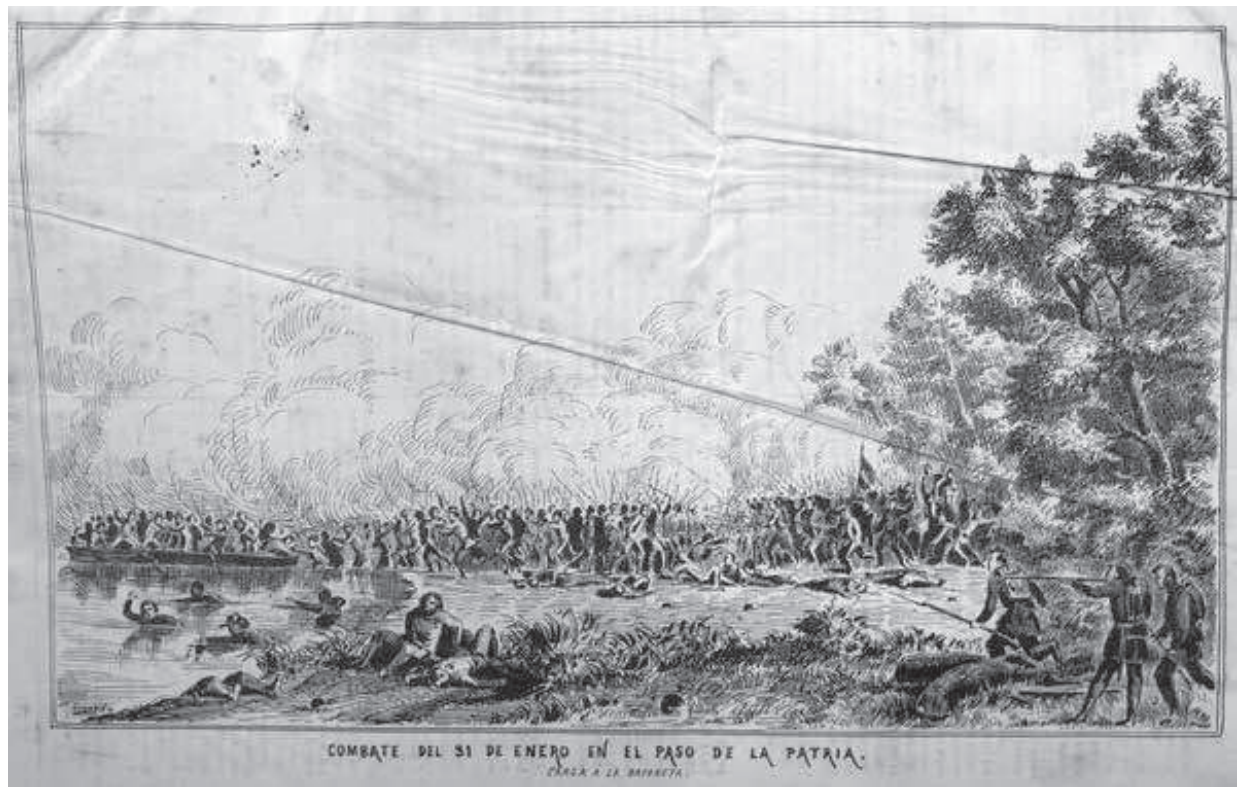

Esta preocupación por no despertar la inquietud de los lectores, dando primacía a las imágenes que muestran una visión suavizada de la guerra, se repite en otras ocasiones. El 4 de marzo de 1866, por ejemplo, el periódico publica en primera plana los retratos de "cinco valientes" de la Guerra del Paraguay. El retrato ovalado del coronel José Bustillo ocupa el centro de la página, rodeado por los retratos de cuatro oficiales ${ }^{24}$. En la contratapa, en cambio, se exhibe la figura de "una lavandera". El semanario explica así la elección de sus imágenes:

Para hacer juego al retrato de los cinco valientes que adornan la primera página del Correo de hoy, mejor cuadraría una cantinera que una lavandera. Pero es preciso respetar los caprichos de los artistas y que al fin tienen su lógica aunque no aparezca a primera vista. Y en efecto, las ideas que despiertan los bravos al frente del enemigo... deben mitigarse con algún espectáculo risueño, con alguna imagen que sonría. Ése es el papel que desempeña a favor de nuestros suscriptores esa joven, ágil y agraciada muchacha que desciende a la verde orilla del río a desempeñar su humilde oficio de lavandera ("La lavandera", Correo del Domingo, 4 de marzo de 1866; énfasis añadido).

La supuesta fuerte impresión que los retratos de los oficiales podían causar en los lectores debía ser apaciguada con la imagen de una figura femenina fuera del contexto bélico. De esta manera, el comentarista exagera la bravura de los retratados -y el poder de impresión de esas imágenes- al tiempo que pretende sosegarlo. Por otro lado, la lavandera no se refiere a ninguna persona en parti-

24 El editorial de ese número anuncia la muerte del General Juan Gregorio de Las Heras, aprovechando una vez más la ocasión para hacer brillar a las figuras de las guerras de independencia. 
cular: "Nuestra lavandera es un tipo de la orilla del Plata, una flor indígena del bajo que el álbum del artista ha recogido para el herbario de costumbres, trajes y usos nacionales que de cuando en cuando reproducirá el Correo del Domingo". Combinándola con los retratos de aquéllos que tienen título, nombre y apellido, la imagen de este "tipo" indirectamente se nutre del discurso realista de los retratos de los oficiales, aun cuando se reconozca la mano del artista. Por lo demás, ambos tipos de retratos juegan un papel en la conformación de la comunidad imaginada de la nación: unos son modelos de héroes, otros son anónimas figuras arquetípicas de la familia nacional.

Rescatando el discurso de salvación del pueblo paraguayo, el Correo también incluye imágenes de la población vecina. Aquí se aleja de la visión de "enemigos" que utilizara Granada, pero enfatiza igualmente el atraso con que juzga a sus habitantes. El 14 de enero de 1866, el periódico dedicó su tapa a una pareja paraguaya. Si bien sujetos anónimos, el semanario subrayó que la litografía era fiel reproducción de una fotografía ${ }^{25}$. Contrastando con las otras imágenes bélicas, en este caso se busca alejar toda sombra de ficción, señalando la fuente $y$ su autoridad irrefutable:

La lámina de la primera página es copia exacta de una fotografía tomada en la Asunción. (...) Estos retratos y varios otros que hemos visto, revelan claramente los efectos de la tiranía de los gobiernos de Francia y los López sobre las costumbres del pueblo paraguayo, muestran las barreras puestas por esa política sombría a la civilización del mundo por el contacto de los pueblos, y prueban la necesidad de una saludable regeneración para ese país que tiene tantos elementos de progreso. La joven viste un traje, cuya tela ha sido admirablemente trabajada por sus manos, y el compañero luce una lujosa manta, obra también de la industria paraguaya; pero ninguno de los dos lleva calzado, y sin él hemos visto numerosas fotografías de soldados de López, en uniforme de parada (“Jóvenes Paraguayos", Correo del Domingo, 14 de enero de 1866).

Este pasaje revela que había una selección consciente del tipo de imágenes a ser circuladas, dibujos o fotografías, según el sujeto a ser representado. Muestra, además, que los editores del Correo estaban al corriente de la cantidad de imágenes fotográficas que estaban en circulación, ignorándolas al momento de representar al soldado argentino y su vida en el campamento. En el caso de la pareja paraguaya, el referente fotográfico funciona como garantía de ver$\mathrm{dad}^{\mathbf{2 6}}$. El uso de esta fotografía refuerza, además, la interpretación oficial de la

25 Una de las primeras imágenes sobre la Guerra dela Triple Alianza que publicó el Correo estaba, de hecho, basada en una fotografía. Se trata de la litografía que cubre la tapa del número del 29 de enero de 1865 . Allí vemos la imagen icónica de la Iglesia de Paysandú destruida por las fuerzas brasileras. Sin embargo, en el cuerpo del periódico no se hace ningún comentario respecto a tan impactante imagen de tapa.

26 La autoridad del referente fotográfico no es una constante en el periódico. Son numerosas las ocasiones en que se indica que el retrato de tal o cual figura pública no ha sido incluido porque las imágenes fotográficas con las que cuentan no les hacen justicia. Otras veces se pondera el poder del dibujo y la pintura por sobre la fotografía: "Yo creo que nadie hará en Buenos Aires el retrato del presidente mejor que Meyer, y eso al correr del lápiz" (Correo del Domingo, 15 de enero de 1865). 
guerra: aquella que la imaginaba como el último eslabón de las luchas contra las tiranías que habían acechado a la región: primero la corona española, luego Rosas, y ahora López. El pueblo paraguayo no era el enemigo, sino la víctima a ser liberada del yugo que padecía a su pesar. La interpretación subjetiva de estas fotografías (pies descalzos como prueba irrefutable de atraso y de los males de la tiranía del Mariscal López) se esconde en la corroboración del relato oficial.

El Correo del Domingo, un periódico que desde su primer número se afana de ser una plataforma de divulgación de los últimos adelantos tecnológicos en materia de prensa y reproducción, es un ejemplo de cómo el libre uso de fotografías, dibujos y pinturas para la creación de litografías no determinaba el significado o el discurso a ellas adscripto. En la improvisada cobertura de la guerra, el semanario aprovechó los límites difusos entre estas imágenes de diferente naturaleza para imponer una visión que defendiera los intereses de una nación todavía demasiado endeble. Los variados usos y objetivos del contenido visual ayudaron a sortear estas tensiones, en el intento de rescatar el imaginario heroico y hasta elegante de la guerra. Litografías de figuras y eventos históricos se mezclaron con imágenes de novelas y tipos sociales en un espacio de innovación visual donde los límites entre los discursos de ficción y realidad no estaban definidos. Así, ilustraciones que imaginaban la vida y sueños de los soldados en el frente de batalla convivían con dibujos reconstruyendo enfrentamientos, fotografías litografiadas, mapas, y retratos, además de imágenes no relacionadas a la guerra. Sin un método claro y consistente para la apreciación de sus imágenes, su política contrastó de manera llamativa con el tratamiento de las imágenes de la guerra en la publicación Álbum de la Guerra del Paraguay (1893-1896), dos décadas más tarde. De fuerte contenido visual, las imágenes aquí incluidas -independientemente de su origen o referente-no buscaban ser prueba de nada. La publicación tomó una posición sumamente cauta respecto a la interpretación y el peso de las imágenes. Quienes querían prestar sus servicios para la interpretación de los documentos, debían hacerlo bajo su propio riesgo: "cada cual asume la responsabilidad de sus versiones y afrontará seguramentela discusión que pudiera provocar" (Álbum dela Guerra del Paraguay, 1 de febrero de 1893).

Unas décadas antes, conviviendo con los inicios de la fotografía, el "buen nombre" de la publicación era legitimidad suficiente para comentar las imágenes con libertad, aun sin tener "autoridad en la materia que trate" (Álbum, ídem). Su veracidad la dictaminaban los intereses y los cálculos del semanario:

El Correo del Domingo debía haber traído hoy cinco retratos, el del coronel Bustillos y los de los cuatro comandantes de los batallones movilizados de la ciudad. ¡Pero qué lástima! El dibujante se había esmerado y tres de esos cinco retratos están muy buenos, pero no así dos de ellos, cuya semejanza deja que desear, sobre todo cuando se trata de personas tan conocidas. Tiempoy trabajos perdidos (Correo del Domingo, 9 de julio de 1865). 
La semejanza era aquí un factor importante, principalmente porque al ser el referente conocido por los lectores, éstos mismos podían juzgar su fidelidad (como el retrato de la cantante de ópera que Cantilo imagina tan efectivo al comienzo de la publicación). Pero en otras ocasiones, la semejanza podía ser un problema:

\footnotetext{
La generación actual conoce las facciones severas del ilustre americano [San Martín] por diversos retratos [daguerrotipos] que le representan en el último tercio de su vida. El que hoy aparece en el Correo le ofrece en aquella edad en que se inflamaba su corazón ante las grandes empresas que había que realizar y los peligros que era preciso afrontar para conseguir la independencia de la América (Correo del Domingo, 15 de enero de 1865).
}

En tiempos de guerra, los dos daguerrotipos de un San Martín anciano en traje civil eran menos convenientes que aquellas pinturas que lo rescataban como el guerrero histórico que la patria quería celebrar.

El libre uso de las imágenes litográficas como fuentes de autoridad para informar sobre eventos pasados fue posible porque el periodismo visual era un discurso aún en formación, sin modos institucionalizados de legitimación, al tiempo que la historiografía ilustrada romántica difundía la aceptación de parámetros más flexibles en el uso de las ilustraciones. Esta fluidez entre los soportes y la ambigüedad respecto al sustrato de verdad o ficción detrás de cada imagen es reflejo de un momento en que las tecnologías visuales no habían sido enmarcadas en las construcciones disciplinarias modernas. Lejos del reemplazo de un medio por otro, la multiplicación de tecnologías disponibles daría como resultado la convivencia e interferencia de imágenes de diferentes naturalezas y objetivos.

Es en este contexto que el Correo del Domingo juega con las diferentes fuentes visuales para fortalecer otro tipo de discurso disciplinario: aquel creador de ciudadanos de la nación argentina, acríticos del gobierno y enaltecidos en su amor a la patria. Gracias a esta indefinición entre ficción y documental de las litografías, el semanario logra defender la idea de que aquella guerra era un evento glorioso más en la naciente historia patria. 


\section{REFERENCIAS}

Amigo, R. (Ed.). (2008). Las armas de la pintura. La Nación en construcción (18521870). Buenos Aires: Museo Nacional de Bellas Artes.

Amigo, R. (2009). Imágenes en guerra: La Guerra del Paraguay y las tradiciones visuales en el Río de la Plata. Nuevo mundo mundos nuevos. Recuperado: 10/9/2017. En línea: https://nuevomundo.revues.org/49702

Bertrand Dorléac, L. (2014). Tournant. En L. Bertrand Dorléac \& Musée du LouvreLens (Eds.), Les désastres de la guerre, 1800-2014 (pp. 16-19). Paris: Lens: Somogy- Musée du Louvre-Lens.

Bilbao, M. (1902). Buenos, Aires desde su fundación hasta nuestros días: especialmente el periodo comprendido en los siglos XVIII y XIX. Buenos Aires: J. A. Alsina.

Boehm, G. \& Mitchell, W. J. T. (2010). Pictorial versus Iconic Turn: Two Letters. In N. Curtis (Ed.), The pictorial turn (pp. 8-26). London: Routledge.

Burucúa, J.E., Malosetti Costa, L., Jáuregui, A. \& Munilla, M. L. (1990). Influencia delos tipos iconográficos de la revolución francesa en los países del Plata. Cahiers des Amériques Latines, 10, 147-157.

Crary, J. (2005). Techniques of the observer: on vision and modernity in the nineteenth century (Nachdr). October books. Cambridge, Mass.: MIT Press.

Del Carril, B. (1984). El grabado y la litografía. En Historia General del Arte en la Argentina (pp. 354-404). Buenos Aires: Academia Nacional de Bellas Artes.

Diaz, S. J. (2009). Against Paraguay.19th Century Latin-American Visual Culture and Literature during the War against Paraguay (1864-1870). University of Michigan, USA.

Eisenstein, E. L. (2011). Divine art, infernal machine: The reception of printing in the West from first impressions to the sense of an ending. Philadelphia: University of Pennsylvania Press.

Melot, M. (1984). Le texte et l'image. En H.-J. Martin, R. Chartier (Eds.), Histoire de l'édition française: Le temps des éditeurs, Du romantisme à la Belle Epoque (1830-1900). Tome 3. Paris: Promodis.

Nouzeilles, G. (2013). The Archival Paradox. En E. Cadava y G. Nouzeilles (Eds.), The itinerant languages of photography (pp. 38-53). Princeton, NJ: Princeton University Art Museum.

Poole, D. (1997). Vision, Race and Modernity: A visual economy of the Andean Image World. Priceton: Princeton University Press.

Samuels, M. (2003). Illustrated Historiography and the Image of the Past in NineteenthCentury France. French Historical Studies, 26(2), 253-280. 
Szir, S. (2009a). De la cultura impresa a la cultura de lo visible. Las publicaciones periódicas ilustradas en Buenos Aires en el siglo XIX. Colección Biblioteca Nacional. En M. Garabedian, S. Szir y M. Lida (editoras), Prensa argentina siglo XIX: Imágenes, textos y contextos (pp. 53-84). Buenos Aires: Ediciones Biblioteca Nacional/ Teseo.

Szir, S. (2009b). Entre el arte y la cultura masiva. Las ilustraciones de la ficción literaria en Caras y Caretas (1898-1908). En Laura Malosetti Costa y Marcela Gené(Eds.), Impresiones porteñas: imagen y palabra en la historia cultural de Buenos Aires (pp. 109-139). Buenos Aires: Edhasa.

Szir, S. (2013). Reporte documental, régimen visual y fotoperiodismo. La ilustración de noticias en la prensa periódica de Buenos Aires (1850-1910). Caiana. Revista de Historia del Arte y Cultura Visual del Centro Argentino de Investigadores de Arte (CAIA), 3. Recuperado: 17/7/2017. En línea: caiana.caia.org.ar

Tagg, J. (1993). The burden of representation: Essays on photographies and histories. Minneapolis: University of Minnesota Press.

Toral, A. A. d. (2008 y 2009). Las imágenes de la Guerra del Paraguay. Revista Estudios Paraguayos, $\mathrm{n}^{\circ} 1$ y 2 (XXVI y XXVII), 215-221.

Viñas, D. (1982). Literatura argentina y realidad política. Buenos Aires: Centro Editor de América Latina.

\section{IDENTIFICACIÓN DE LA AUTORA}

Candela Marini es investigadora en la Universidad de Duke, Carolina del Norte, EE.UU., donde realiza un doctorado en estudios interdisciplinarios latinoamericanos. Ha publicado ensayos sobre narrativa contemporánea latinoamericana y coeditado un volumen sobre estudios sonoros para la revista electrónica Critical Reviews on Latin American Research (CROLAR), de la Universidad Libre de Berlín (FU). Su tesis doctoral estudia la fotografía de guerra decimonónica, en Argentina y Chile, en el contexto de las campañas militares de expansión territorial y genocidio indígena.

\section{REGISTRO BIBLIOGRAFICO}

Marini, C. (2017). El patriotismo del Correo del Domingo: ficciones de guerra y soldados. InMediaciones de la Comunicación, 12(2), 73-97. 